\title{
Teaching Practice in Acculturation Educational Settings: A Case Study on an Integration Course
}

\author{
Julio César Tovar-Gálvez
}

Department of Didactics of Biology, Institute of Biology, Faculty of Natural Sciences I - Biosciences, Martin Luther University Halle-Wittenberg, Germany

\section{ARTICLE INFO}

\section{Keywords:}

Acculturation

Diversity

Interculturality

Pluralism

Teaching

\begin{abstract}
Teaching practice has the potential to guide acculturation educational processes to cultural inclusion. Acculturation may lead to social tensions or peaceful connivance. An acculturation process might be inclusive when educational participants symmetrically recognise, validate and use the different cultures as part of the curriculum. The Cultural Bridge (CB) is an approach that teachers might use to design inclusive teaching practices. The method is a qualitative case study on an integration course in Germany. Results evidence a partially inclusive educational process. According to the teacher's interview analysis, the teaching practice approximates the $\mathrm{CB}$ principles, but there are limitations because of the system and social barriers. The most relevant situations that limit the teacher's practice are the rigid curriculum, the test as the primary goal, the short time for addressing the mandatory topics and the students' social isolation. As a recommendation, integration courses might engage the local community in the educational process.
\end{abstract}

\section{Introduction}

Teaching practice has the potential to guide educational acculturation processes to cultural inclusion. Acculturation is every change that communities experience during the contact between different cultures (Gibson, 2001; Redfield, Linton \& Herskovitz, 1936). Those changes may lead to social tensions or peaceful connivance (Manthalu \& Waghid, 2019). An acculturation process might be inclusive when educational participants symmetrically recognise, validate and use the different cultures as part of the curriculum. This paper aims to describe the teaching practice of a teacher in an integration course. The German government offers the integration course to refugees and other immigrants to integrate them into German society. This course consists of a part of German language learning (600 lesson units) and a part called 'orientation course' about the German political system, history and society (100 lesson units). Each part ends when participants take a test. In this context, the question arises: does the teaching practice lead to inclusive acculturation in the integration course?

Through their teaching practices, teachers involve students in different acculturation processes. For example, Makarova \& Herzog (2013) study the correlation between teachers' attitude towards immigrant students' acculturation process and the propensity to punish students. The

\footnotetext{
${ }^{*}$ Corresponding author E-mail address: joule_tg@yahoo.com, http://orcid.org/0000-0001-7008-5140 Journal of Teaching and Education, 3(1):20-33. https://doi.org/10.33422/ejte.v3i1.655
} 
results reveal a correlation between teachers' acculturation strategy (integration, assimilation, separation or marginalisation) and the tendency to punish students. In the same direction, Makarova, Gilde \& Birman (2019) identify the teaching practice (content, methods, activities, teaching style, competences, communication, among others) as a risk factor for students' acculturation process. Salloumk, Siry \& Espinet (2020) address the sense negotiation and learning access problems in multilingual contexts. From this perspective, teachers conduct acculturation as power relationships through language. According to this, the teaching practice might lead to negative or positive acculturation processes in educational settings.

Some approaches might describe acculturation as the interaction between cultures as curriculum content at the didactic level (planning, teaching, learning and assessment). For instance, Mpofu, Otulaja and Mushayikwa (2014) propose four types of integration substitutive, divergent, parallel, and convergent. In the same line, Ludwig and El-Hani (2020) identify two cultural interactions in the classroom -ignorance of the minority knowledge systems and overlapping the minorities' knowledge systems under the mainstream knowledge system. For studying or guiding approaches in teaching and learning, and the teacher education and practice in culturally diverse contexts, Tovar-Gálvez \& Acher (2019) bring the inclusion to the didactic level. Their idea about epistemological inclusion here is generalised as cultural inclusion. Cultural inclusion in educational settings happens when society -a) recognises the cultural pluralism at the school (Guédez, 2005), b) validates the contribution of every culture to the subjects' education (López \& Küper, 1999), and c) uses the different cultures as part of the curriculum (López \& Küper, 1999; UNESCO, 2008). Those values recognising, validating and using, are the base to develop a framework for teaching practices that lead to inclusive acculturation processes.

\subsection{The Cultural Bridge as a Framework to Design Culturally Inclusive Teaching Practices}

The Cultural Bridge (CB) is an approach to design culturally inclusive teaching practices. When teachers use the $\mathrm{CB}$, they count on practical guidance to symmetrically recognise, validate and use the different cultures in the curriculum. With the $\mathrm{CB}$ guidance, teachers engage students and communities to cross their cultural borders, having the opportunity to enter other cultures and learn about them. This transiting between cultures is in every direction and every time. Communities involved in the $\mathrm{CB}$ process do not leave their cultural identities and commitments. Instead, communities obtain elements to adapt to new cultural settings while preserving or rescuing their cultures. The different communities in a diverse context cross the borders of their cultures to learn about the others. Individuals decide if they finally remain in the new cultural context, the walkway between cultures, their original culture, or in permanent transit. Whatever the decision, the individuals with the $\mathrm{CB}$ experience would already know other cultures by the end.

The $\mathrm{CB}$ is a generalisation of the Epistemological Bridge (EB) proposed by Tovar-Gálvez (2021). For the author, culture is a set of elements that constitute subjects and communities identities. Those elements could be communities' history, traditions, customs, language, religion or beliefs, social organisation, politics, art, epistemologies and much more other human constructions. Under this consideration, the EB is a process during which teachers engage students in using the epistemologies of the different cultures to solve problems or explain situations. In this case, the epistemologies represent a system of ideas, production practices and legitimisation practices belonging to each culture. However, the $\mathrm{CB}$ as a generalisation encompasses more cultural elements than only epistemologies.

Following Tovar-Gálvez (2021), two practical principles emerge from the CB to guide teachers to design culturally inclusive teaching practices. First, the Cultural Independence principle represents every culture as an independent endpoint of the bridge. This independence comes from pluralism. As a position, pluralism (Habib, 2017; Santos, Nunes \& 
Meneses, 2008) recognises every culture and validates its inherent value. For teachers, pluralism is practical when they recognise the convergent cultures in the classroom and validate them as part of the curriculum without distinctions. Second, the Cultural Similarity principle represents the walkway of the bridge. This similarity arises from interculturality. As an approach, interculturality (Valladares, 2011; Walsh, 2009) is the possibility of a respectful interaction, negotiation, mutual learning and cultural border crossing by taking advantage of the common interests, values, aims, and more elements between cultures. For teachers, interculturality is practical when they recognise commonalities between cultures and use those commonalities to guide students in the border crossing.

\section{Method}

\subsection{Focus}

This report is a case study conducted from a qualitative perspective. According to Zainal (2007), a case study is a methodology that addresses a phenomenon in a specific context. The author points out that the researchers who use this methodology access information that surveys cannot provide, e.g. the reasons and senses individuals give to reality. In the present research, it is essential to know about the teaching practice and also the critical reflections of the interviewed on the acculturation process. Díaz, Mendoza and Porras (2011) state that case study analyses a unity with a particular behaviour, but related to a general research problem, field or theories. This research is specific regarding the context, but is in the educational research and cultural studies frame. Additionally, the discussion section contrasts the local results with other reports and theories of the research field. As case studies have limitations to produce generalisations, this research does not conclude with affirmations but with recommendations to design inclusive acculturation educational processes.

\subsection{Data Resource}

A teacher provides information regarding her practice in the orientation course in Germany. She earned a bachelor title in English Language and Literature, Pedagogy at the Yerevan State University in Armenia and a master title in German as a Foreign Language at the Martin Luther University of Halle-Wittenberg in Germany. She is giving the German language part of the integration course since 2016. Currently, she is teaching at a language school in Leipzig, Saxony, Germany.

\subsection{Data Collecting}

Through a depth interview (three cycles), the teacher spoke about students' learning, and about her teaching and assessment methodology, and relationships between cultures in the integration course. Additionally, the teacher reflected on limitations and proposals to establish an inclusive relationship between cultures in the integration course. Following the founded theory (Glaser \& Strauss, 1967; Páramo, 2015), the researcher identified emerging categories by coding and grouping the information provided by the teacher. A second analysis of the information is through the Cultural Bridge approach. For this process, the researcher identifies how the case meets Cultural Independence and Cultural Similarity principles.

\subsection{Reliability}

The reliability of the data rests objectively on the profile of the teacher interviewed and subjectively on the researcher's philosophy. Objectively, the teacher is a professional in education and specifically in teaching German as a foreign language. This aspect is verified by the academic qualifications already named. Additionally, the teacher has a formation in educational research and, more specifically, German teaching taking cultural aspects into account. The teacher's speech proves this argument during the interview. She mentions her 
masters' research project on German teaching by using literary texts to address cultural aspects of the language. Furthermore, the teacher has worked leading the integration course for six years and with several groups. This working experience from her research point of view constitutes a reliable data resource. Finally, from the objective point of view, the discussion section contrasts the research results with other research reports and other theoretical frameworks - this contrast of data and theory makes evident convergences to the corpus of the research field.

From the subjective point of view, the researcher assumes the interviewed teacher as a valid interlocutor. From the beginning, the teacher knew that the research process was not an evaluation of her pedagogical practice, but a way of better understanding acculturation within the framework of the integration course. For this reason, the researcher considers that the teacher was not under pressure, and therefore, she was transparent regarding her testimony and reflections. Likewise, the researcher recognises the professional and investigative profile of the teacher. Finally, as a validation process, the teacher reviewed the interpretation of the data made by the researcher.

\section{Results}

\subsection{Emerging Category "Description of The Teacher's Practice"}

3.1.1. Structure, Aim and Methodology

The course is oriented to students to take The European Language Certificate for German. The methodology, materials and books are for preparing students for the exam. Teachers must follow an action-oriented methodology to develop the student's skills (listening, reading, speaking and writing). This methodology is mainly focused on the test and, to a lesser extent, on everyday life. Teachers have a Model Text Book and students have a book structured under this methodology. In this regard, teachers must use the book. In levels A1 and A2, texts are very structured to the TELC, but in levels B1 and B2, students also can learn about official aspects of the Foreigners Authority, Employment Office and Job Centre. The curriculum also includes some projects, during which students must prepare some materials and introduce them to the class. Those projects are more flexible than the regular lesson in introducing cultural aspects (from Germany and students' countries). The teachers' book also establishes the assessment methodology based on points. Flexibility in teaching, formative assessment and cultural contents are minimal because of the short time, extensive contents and the established methodology.

\subsubsection{Limitations Perceived from Students}

The students' main limitation is the writing skill because most of them must learn the Latin script. Another problem is that for the students, it is difficult to understand the German language in official situations. In the studied case, the teacher indicates that some topics are not interesting for students, such so specific information of the history, but they must learn it for the exam. The teacher finds a substantial limitation that most students do not have contact with Germans because they live in neighbourhoods only inhabited by refugees. She finds the attitude of some students a minor problem since they do not want to attend the class and only sign the attendance list.

\subsubsection{Limitations because of the system}

The standardised curriculum establishes contents, materials and time. As the language content is so extensive and the methodology structured, teachers must follow strict rules to lead students to the test. For this reason, teachers have no much opportunity to be flexible. The interviewed teacher considers that the integration course is more focused on the language than the German culture, which is not enough for learning. She thinks that it could be convenient for some teachers to have everything defined by the system, but this is not the 
best way for integration. The teacher would like to introduce some elements she has learned during her master at the university. But those innovations are not possible because of the short time. Additionally, the teacher identifies as a relevant problem the integration course focus on learning German as a second language and not as a foreign language. When people learn German in foreign countries, teachers are responsible for teaching about the culture, and it is part of curricula. When people learn German in Germany, teachers teach the language, and students learn about the culture in context. This situation has a repercussion for integration because, as she said, many students do not have actual contact with Germans.

\subsubsection{Cultural Interactions Which Shape the Teaching and Learning Process}

The teacher, in this case, uses cultural interactions to conduct the teaching and learning. She reports on the confidence atmosphere reached when she allows students to express their feelings and opinions. Similarly, the teacher has no problems when students ask her about her country, traditions and beliefs. In another way, she considers the students' cultures and communication styles to guide the feedback process in the lessons. The teacher identifies that people from some regions are open, talkative, and confident, whiles people from other areas are more conservative or shy to communicate.

\subsection{Emerging Category "Teaching Practice and Integration"}

\subsubsection{Integration Limitations}

The little time and the methodology are the most important limitations to lead students to integrate into the German culture. The teacher several times refers her intention to introduce in the lessons cultural aspects through specific methodologies she learned during the master. However, for those innovative strategies, she would need a long time and curriculum flexibility. The topics in the book are not enough for students to know the German culture, and not all the issues motivate students to learn. The contents addressed during the orientation course, after the language course, are limited (politic system, history and society). Finally, students approximate some everyday aspects through the book, but they have few opportunities to interact with Germans and their culture in real life.

\subsubsection{Integration Opportunities}

A few elements in the current integration course structure contribute to lead students to an authentic integration into the German culture. For instance, the book units include situations that students live in everyday life. Likewise, as part of the established methodology, the projects can introduce cultural aspects regarding students' countries and Germany. The main topics developed during the Orientation course are a part of the multiple dimensions of culture.

\subsection{Emerging Category "The Teacher's Reflections On the Teaching Practice and Proposals"}

\subsubsection{Teaching Method Based on Research}

The interviewed teacher proposes a teaching method based on literary texts to introduce cultural elements and help students integrate into the German culture. During her master in German teaching as a foreign language, she took seminars about the cultural dimension in language teaching. Based on this, she wrote her master's thesis on using literary stories in teaching German. This academic experience is the position from which she argues that - "the most proper way to integrate people to a new society is to teach them about the culture of the country. And I do not think that some political facts are enough in order to integrate people (...)". She explains that there is an extensive literature of short text that contributes to introducing a cultural dimension to the lessons. The teacher highlights a part of this literature 
written by foreign writers who came to Germany as children or were born into immigrant families.

\subsubsection{Formative Assessment Method}

The teacher in this case study understands assessment as feedback and a culturally sensitive process. She describes that she would like to implement more often learning's assessment based on the students' criticism of their work. The traditional assessment system established in the book centred on the teacher criteria is not productive enough for her. She considers that the teachers should underline the mistakes to encourage students to find the errors by themselves. And finally, students report on the found mistakes to the teacher. Additionally, the teacher takes into account the students' cultural communication ways to conduct this process.

\subsubsection{Emotional Education}

The teacher appraises as central the development of empathy towards the German culture to lead the student to integration. She argues that it is possible through teaching based on literary texts. For the teacher, integration means empathy to the country and teaching the culture might develop such empathy. However, from her point of view, the integration course currently puts the cultural dimension of language on a second level. Students probably will identify themselves when they read texts about integration experiences written by foreigners. And students likely will develop empathy while reading short texts about the German traditions. In conclusion, the teacher claims - "if you don't like it [the country], you don't have any emotional connection to the language, the culture, everything, and you only use the language as a tool, you don't feel like a part of society, and it is not integration".

\subsection{From the Cultural Bridge Perspective}

The case teacher's practice approaches a bridge between cultures, but with limitations due to the structured curriculum. The practice meets the cultural independence and cultural similarity principles in different ways. The limitations associated with the curriculum are regarding contents, methodology, materials and time. The students have few opportunities to interact with Germans is a social situation that restricts learning the German culture and cultural interaction.

\subsubsection{Cultural Independence (CI)}

(a) Cultural Independence enactment during the teacher's practice: The teacher guarantees CI through her practice because the German culture, students' culture, and teacher's culture are part of the lessons. She allows students to express their feelings, consider their cultures to conduct the communication, and share about her country with students. Thus, the teacher reaches a balance. Additionally, to the German culture incorporated in the book and materials, the cultures of students and teacher are also part of the lessons. The teacher declarations do not evidence a specific prevalence of a culture or the rejection of any culture.

(b) Cultural Independence enactment in the teacher's learning: The teacher assures CI when she learns about the students' cultural aspects. During interaction with students, the teacher has noticed behaviours and situations that she did not understand initially. Nevertheless, as she reported, she asked other teachers or had to read about these aspects to understand the cultural reason finally. Consequently, the teacher recognises the diverse cultures in the classroom.

(c) Cultural Independence enactment in the teacher's proposal: The teacher's didactic proposal is a prospect of CI consolidation. She considers that the integration course does not 
immerse students into the German culture. For this reason, she suggests introducing elements of the German culture more than the political and historical facts. She proposes short literary texts, fairy tales and life stories to include immigrants' cultures and the German culture to the lessons.

(d) Cultural Independence limitations: The teacher considers that the focus of the integration course does not contribute to students' opportunities to learn German culture. She thinks that the course is limited to teaching German as a second language and not as a foreign language. She explains that when people learn German in foreign countries, the cultural dimension is part of the curriculum. Nonetheless, when people learn German in Germany, the curriculum is focused on the language. In this order, it is supposed that students learn the language at the school and the culture outside. However, students' reality is that they live in neighbourhoods where the most inhabitants are foreigners. This situation means that students do not have so many possibilities to learn more about the German culture.

\subsubsection{Cultural Similarity (CS)}

(e) Cultural Similarity enactment from the system: The model textbook opens an opportunity for the CS enactment. The section "projects" is a scenario where communities meet, cross their cultural borders to a commonplace, and interact. The teacher describes projects as moments during which students must prepare materials and introduce them to the class. Moreover, she argues that projects are a flexible activity where it is possible to introduce the cultural dimension to the lessons.

(f) Cultural Similarity enactment during the teacher's practice: The teacher enacts the CS during the lessons in different modalities. First, she identifies and considers the cultural characteristics to motivate the communicative interaction. Second, she feeds the student's identification with the teacher, taking into account the common condition as foreigners. Third, she now expects to invite Germans to participate in the lessons to promote cultural interaction. Fourth, she identifies as a common aim that students desire to learn the language and the German culture, no matter their origin or background.

(g) Cultural Similarity enactment during the teacher's proposal: The teacher's didactic proposal has the potential to fostering cultural interaction. Thus, she advises developing the students' cultural empathy. This empathy could promote better communication and more willingness to learn and be part of German society. Additionally, she argues that students might reach this empathic attitude through literary texts from different cultures. In this order, the teacher identifies literary texts as a commonality between cultures to motivate the cultural interaction.

(h) Cultural Similarity limitations: The teacher's claims evidence many reasons for the CS enactment restriction. She states that the curriculum and materials do not provide enough information and opportunities for cultural interaction. This limitation redounds on the students' empathy for the German culture. Likewise, she points out as a relevant cultural barrier specific beliefs and customs. She expresses that she is unwilling to change her dress and behaviour just because some people are conservative because of their religion. She adds that many Germans cannot accept the low hierarchy that women have in some societies. Another limitation for enacting cultural interaction is that perhaps Germans are unwilling to participate in the integration course context. She says that she knows some Germans interested in her experience as a teacher for immigrants. Many Germans are interested in participating in some cultural acts and tasting some food. However, she thinks that they are not interested in a deep knowledge of foreign cultures. Finally, she expresses that students' have no opportunities to interact with Germans because they usually live in neighbourhoods for immigrants. 


\section{Discussion}

\subsection{Does the Teaching Practice Lead to Inclusive Acculturation in The Integration Course?}

From the Cultural Bridge approach, this is a partially inclusive acculturation educational process. The teacher's practice enacts the CI and CS principles. Nonetheless, there are limitations because of the curriculum and some social situations. Those two factors limit inclusion in the whole educational process.

Specifically, the teacher's practice in the case is inclusive because the teacher guarantees cultural independence (CI) and cultural similarity (CS). However, the teacher's practice depends on the established system -curriculum, methodology, textbooks, and short time. The participants reach the CI principle in good measure. The teacher and students can introduce some elements of their foreign cultures to the lessons by themselves. Nevertheless, the curriculum has limitations regarding elements of the German culture. The participants meet the CS principle with limitations. The teacher and students have some experiences in which they cross their cultural borders to interact with their foreign cultures. Nonetheless, the curriculum offers few opportunities for cultural interaction. Additionally, there are insurmountable cultural barriers, such as the position of women in some regions compared to the Western one. Finally, the cultural interaction is minimal because the Germans do not participate in the curriculum, and students usually do not contact Germans.

The Cultural Bridge process consists of the transiting between the different cultures (German and foreigners) in all directions. Thus, for the integration course to meet the bridge between cultures, Germans and foreigners should cross their cultural borders and transit to the other cultures. As only the students (foreigners) try to cross to the German culture, the inclusion is restricted. The Cultural Bridge process is dynamic and offers the communities (Germans and foreigners) the opportunity of learning from each other. For this reason, during the integration course, Germans and foreign students should learn about each culture. As only students approximate to learn German language and the local culture, the inclusion is narrowed. The Cultural Bridge process offers the individuals the possibility of staying in any part of the bridge but knowing the different parts. Considering this condition, the integration course guide individuals to choose whether to remain in one place on the bridge or to remain in constant transit.

An educational community does not enact the Cultural Bridge when the cultures are not part of the curriculum, when only one of the communities transit to the other culture, or when the transit is an imposition. In those cases, acculturation is a change that only happens in a specific community (the foreigners). However, in real life, such situations not always succeed at the same time or all the time, so the acculturation will meet the Cultural Bridge principles partially. Consequently, an acculturation educational process that partially meets the CI and CS principles is partially inclusive.

\subsection{Convergences to Other Cases}

The integration course, as the teacher has described it, converges to other proposals and cases. In a way, the integration course matches reports on processes focused on motivating minorities to be integrated into the mainstream. On another way, integration course joins studies focused on encouraging all the communities to learn from each other.

Regarding the first convergence, Aikenhead \& Michell (2011) consolidate the concept of border-crossing used to design educational processes devoted to bridging cultures. The authors propose didactic elements to develop a curriculum that considers the students' cultural background to conduct teaching. Specifically, the researchers propose to teachers and educators recognising indigenous knowledge as a way to understand the physical world. Moreover, they also propose a mechanism to support indigenous students to cross their cultural borders to enter the mainstream culture easily. With a similar aim, Terranova- 
Cecchini \& Toffle (2014) report on a tool designed to connect the refugees to their cultural roots. Through this tool, the refugee program seeks to reinforce the foreigners' identities in the new cultural context. Those two advancements in conducting acculturation through education contribute to recognise and empower communities' cultural backgrounds. This goal only engages the minorities in crossing the bridge to the mainstream culture, as the standardised integration course in Germany.

The second convergence is to the report by Tovar-Gálvez \& Acher (2021). The authors support teachers in enacting a bridge between epistemologies of different cultural backgrounds. In this case, the teacher guided by the authors uses indigenous knowledge, rules and practices as part of the curriculum. The teacher engages students to explain an everyday situation from science and the indigenous perspective. The students belong to the mainstream mestizo community, and there are no students who identify themselves as indigenous. In this same line, Profanter \& Lintner (2011) argue the need to engage the dominant culture communities in learning about the cultural minorities. For the researchers, cultural distance and social isolation happen when the communities do not know about the others. An alternative to ending marginalization is to provide the dominant culture with knowledge and experiences about and with the minority.

\subsection{Integration in The Context of the Integration Course}

Integration in the context of the 'integration course' is closer to an assimilative and excluding approach than an inclusive one. In the official sources, there is not an explicit idea about what integration is, and about how this concept guides the design and evaluation of the integration course. The limited information about the integration course foundations points to a process in which the minority adopts the local culture. The specialised literature reports on diverse understandings which range from integration as loss of cultural identity to culturally plural interaction. From the framework developed in this paper, the integration course methodology and contents do not meet the cultural inclusion conditions.

The official sources describe integration more close to a process in which immigrants adopt the German language and some other information about the history and life in the Federation. The Federal Office for Migration and Refugees (n.d) webpage, in the 'integration' section, refers to the course aim, but not at the foundations. In this section, stakeholders can read that the motivation for taking the course is "(...) to meet new people, to make yourself understood in everyday life, and to find work". The Federal Ministry of the Interior (2014) offers an online brochure describing that the integration course aim is preparing immigrants for communication in everyday life. The Residence Act (Federal Ministry of the Interior, 2008 and amended in 2020) displays chapter 3 about integration, and without an explicit definition about 'integration', presents section 43 regarding the integration course. This section describes that foreigners receive support for integration, focusing on the process in the integration course. The course aim defined in this section suggests support for foreigners to learn German and be independent in everyday life in Germany. This aim is not explicit regarding recognising and fostering immigrants' culture, neither native's participation in the cultural interaction:

The integration course is intended to successfully teach the German language and knowledge of Germany's legal system, culture and history to foreigners. In this way, foreigners are supposed to become acquainted with the way of life in the federal territory to such an extent as to enable them to act independently in all aspects of daily life, without the assistance or mediation of third parties. (Federal Ministry of the Interior, 2008).

The framework curriculum for the integration course (Goethe-Institut, 2016) does not present a clear and explicit concept of integration. However, it is possible to identify that integration 
is what immigrants must do to be part of German society. The framework curriculum aims to define the learning objectives and content of the integration course and employment and intercultural issues. Nonetheless, this framework is not a curriculum, it does not establish teaching methodologies, and it does not resolve limitations in learning and interculturality. Instead, the framework is a guide for designing courses, books and materials, for which it shows the social contexts in which immigrants must act and their linguistic needs. Teachers can use it to check whether the books and materials are adequate to meet the learning objectives.

On the previous basis, the integration course aims to promote the integration of immigrants through "citizen participation and equal opportunities". Added to the above is the crosssectional area "diversity and interculturality" to guide immigrants in understanding the "conventions, values and norms" of the local culture. In contrast, the testimony of the interviewed teacher shows that a) she cannot dispense with parts of the book and change them for others that she considers more pertinent, b) the contents of the book provide information that does not necessarily lead students to the citizen participation or equal opportunities, and c) students learn about Germany, but hardly interact with Germans and their culture.

The framework curriculum also states that communication in German is the basis for immigrants to participate in German social processes (daily life, education, rights, duties and work). Likewise, the framework declares that the language marks membership in a social group and that integration is a two-way process that affects the migrant and the host society. These claims also contrast with the teacher's testimony since a) she considers that the book's contents are not enough to say that students learn about German culture, and b) the interaction between students and Germans is scarce in everyday life and is null in the integration course.

Regarding the specialised literature, one trend understands integration as a cultural fusion that reduces social tension, but at the same time, reduces cultural diversity. For Kuran and Sandholm (2008), integration leads individuals from different cultural communities to hybridization. The authors argue that the cultural interaction between immigrants and locals results in interchanges, reducing cultural differentiation. As a result, between the communities emerges a common culture that differs from the originals. Wagener (2009) analyses as the integration policies lead immigrants and natives to a uniform lifestyle based on common values. In contrast, as the teacher of the case describes, the integration course is far from this perspective. The main reason for this asseveration is that locals do not participate in the integration course development. Such a situation demonstrates that only immigrants try to cross the cultural bridge, identifying some shared elements between their cultures and the missing local culture.

Another literature trend understands integration as an equilibrium between the immigrants' culture and the local mainstream culture. Berray (2019) interprets integration as preserving the own culture while contributing to the local society. Swaidan (2018) assumes that integration consists of maintaining the original culture and participating simultaneously in the dominant culture. This trend converges to the Cultural Bridge and, therefore, to the idea of inclusion. The CB guides teachers to differentiate and respect the various cultural domains and count on them as content. Teachers might introduce this idea in the classroom using the Cultural Independence principle, which has its ground in cultural pluralism. Moreover, the $\mathrm{CB}$ guides teachers to the borders-crossing and cultural interaction process. Teachers might enact this idea in the classroom using the Cultural Similarity principle, which has its ground in interculturality. However, the $\mathrm{CB}$ demands the participation of immigrants and locals in the process, as it occurs in the first integration understanding.

Wagener (2009) provides on a key idea regarding the nature of integration in the integration course in Germany. The author addresses integration in contrast to assimilation, 
understanding the latter as the process during the immigrant adopts the natives' culture. In this process immigrants abandon their cultures and are more and more similar to locals. From this conceptualization, the author refers to the policy instruments, providing light to the educational process. And taking into account the testimony of the teacher in this case, integration in the integration course is more close to assimilation, because:

(...) an assimilationist approach aiming at converging to a pre-dominant core culture may put more emphasis on the teaching of national history, the learning of the domestic language, or the adoption of artefacts from literature to cooking; an integrationist approach may put more emphasis on general values (human rights, tolerance, etc.) or skill transferability. (Wegener, 2009).

\section{Conclusions (Recommendations for Inclusive Acculturation Processes)}

\subsection{Flexibility as a Way to Better Answer to The Students' Learning Needs}

Official institutions usually assume standardisation of the processes as a synonym of quality. Besides the administrative advantages of standardisation, educational processes need a level of flexibility. Teachers as education and language education professionals have the foundations and experience to understand the students' learning needs and provide possible solutions. Students' learning needs and social situations are not a standard. Moreover, the teachers who are the ones who best know the students' learning requires the opportunity to propose new teaching and assessing strategies. Likewise, teachers might contribute to introduce contents closer to the particular students' needs and interest. Nonetheless, flexibility does not mean destabilising the standard structure but rather creating certain degrees of freedom in the educational process.

\subsection{Integration as Foundation and Praxis}

Integration from an inclusive view and as praxis should be the foundation of the integration course. First, integration from an inclusive approach might consider recognising, validating and using students' cultures as part of the curriculum. From this perspective, students can learn about the different cultural domains and identify common elements for communication. Second, an inclusive integration has limitations when only immigrants experience the acculturation process. If natives are not part of such an acculturation process, then the immigrants are assimilated into the local culture. For this reason, integration cannot be only the denomination of the course but the foundation and praxis of the course. Currently, the integration course provides students with language for everyday life and information about the political system, history and German society. Those contents are an approximation to the German culture, but it is not a real interaction between cultures. Consequently, integration founded in the interaction must guide the course and conduct teaching and learning assessment.

\subsection{Local Citizens' Engagement and Opening}

Cultural interaction might start with communication between immigrants and locals. The integration course has a limit in time, but some interaction opportunities probably foster integration. However, in addition to the interaction into the course dynamic, other interaction places, spaces or programs should be part of the course connections. Opening the course and opening society is a way to impulse cultural interaction and consequently integration.

\subsection{Teacher's Case Proposals Are Transferable}

The interviewed teacher has expressed some proposals that are transferable. The teacher proposes teaching supported on literary text written for Germans and immigrants, learning based on empathy, and an assessment grounded in feedback. Those topics can introduce the 
cultural dimension to the curriculum and lead immigrants and locals to integration. This case is evidence of the teachers' educational and intercultural competence. Teachers are professionals and can contribute to the collective construction of new conceptions and practices of the integration course. The integration course should emerge from the integration between German authorities, teachers, immigrants and German citizens.

\subsection{The Cultural Bridge as an Approach for Supporting Teachers}

The Cultural Bridge is an alternative at the didactic level (planning, teaching, learning and assessment) that guide teachers to design culturally inclusive practices. In this research, the $\mathrm{CB}$ has been used as a framework to interpret the case teacher's practice. This analysis evidence advancement and limitations to inclusion in the integration course context. Nevertheless, the $\mathrm{CB}$ is an approach for teacher education and continuous professional development. From a research perspective, it is necessary to report more cases using the CB for planning, enacting and assessing educational processes. Furthermore, it is necessary to evaluate the $\mathrm{CB}$ contribution to the motivation of inclusive acculturation educational processes.

\section{Acknowledgment}

This paper is an output of the research project "study of the acculturation in the integration courses for immigrants in Germany using the cultural bridge approach" (40.21.0.003SO) funded by the Fritz Thyssen Foundation, Germany. I am really grateful to the teacher who participated in this process and to Prof Dr Martin Lindner at MLU Halle-Wittenberg for supporting me.

\section{References}

Aikenhead, G. and Michell, H. (2011). Bridging cultures: indigenous and scientific ways of knowing nature. Ontario: Pearson Education.

Berray, M. (2019). A Critical Literary Review of the Melting Pot and Salad Bowl Assimilation and Integration Theories. Journal of Ethnic and Cultural Studies, 6, 142-51.

Díaz, S., Mendoza, V. \& Porras, C. (2011). Una guía para la elaboración de estudios de caso. [A guide to developing case studies]. Razón y palabra, 75, 1-25. https://bit.ly/3gamn3R

Federal Ministry of the Interior. (2008). Residence Act in the version promulgated on 25 February 2008 (Federal Law Gazette I p. 162), most recently amended by Article 4b of the Act of 17 February 2020 (Federal Law Gazette I p. 166). https://www.gesetze-iminternet.de/englisch_aufenthg/englisch_aufenthg.html

Federal Ministry of the Interior. (2014). Welcome to Germany. Information for Immigrants. Paderborn: Bonifatius GmbH Druck-Buch-Verlag.

Federal Office for Migration and Refugees. (n.d). Integration. Retrieved March 15, 2021, from https://bit.ly/3x180oj

Gibson, M. (2001). Immigrant adaptation and patterns of acculturation. Human Development, 44(1), 19-23. https://doi.org/10.2307/26763493

Glaser, B. and Strauss, A. (1967). The discovery of grounded theory: strategies for qualitative research. New York: Aldine.

Goethe-Institut. (2016). Rahmencurriculum für Integrationskurse Deutsch als Zweitsprache. München: Goethe-Institut on behalf of the Federal Ministry of the Interior. 
Guédez, V. (2005). La diversidad y la inclusión: implicaciones para la cultura y la educación. [Diversity and inclusion: implications for culture and education]. Sapiens. Revista Universitaria de Investigación, 6(1), 107-132. http://www.redalyc.org/pdf/410/41060107.pdf

Habib, H. (2017). A study of cultural pluralism and its advantages for education. Shanlax International Journal of Education, 6(1), 88-93. http://www.shanlaxjournals.in/article/ education/v6n1/17.pdf

Kuran, T. \& Sandholm, W. (2008). Cultural integration and its discontents. The Review of Economic Studies, 75(1), 201-228. http://www.jstor.org/stable/4626193

López, L. and Küper, W. (1999). La educación intercultural bilingüe en América Latina: balance y perspectivas. [Intercultural bilingual education in Latin America: balance and perspectives]. Revista iberoamericana de educación, 20, 17-85. http://rieoei.org/historico/ documentos/rie $20 \mathrm{a} 02 . \mathrm{htm}$

Ludwig, D. and El-Hani, Ch. (2020). Philosophy of ethnobiology: understanding knowledge integration and its limitations. Journal of Ethnobiology 40(1), 3-20. https://doi.org/ $\underline{10.2993 / 0278-0771-40.1 .3}$

Makarova, E. and Herzog, W. (2013). Teachers' acculturation attitudes and their classroom management: an empirical study among fifth-grade primary school teachers in Switzerland. European Educational Research Journal, 12(2), 256-269. https://doi.org/10.2304/eerj.2013.12.2.256

Makarova, E., Gilde, J. and Birman, D. (2019): Teachers as risk and resource factors in minority students' school adjustment: an integrative review of qualitative research on acculturation. Intercultural Education, 30(5), 448-477. https://doi.org/10.1080/14675986.2019.1586212

Manthalu, C. H. and Waghid, Y. (2019). Decoloniality as a viable response to educational transformation in Africa. In: C. H. Manthalu \& Y. Waghid (Eds.), Education for Decoloniality and Decolonisation in Africa. Cham: Springer International Publishing. https://doi.org/10.1007/978-3-030-15689-3

Mpofu, V., Otulaja, F. and Mushayikwa, E. (2014). Towards culturally relevant classroom science: a theoretical framework focusing on traditional plant healing. Cultural studies of science education, 9, 221-242. https://doi.org/10.1007/s11422-013-9508-5

Páramo, D. (2015). La teoría fundamentada (Grounded Theory), metodología cualitativa de investigación científica. [Grounded Theory, qualitative scientific research methodology]. Pensamiento \& gestión, 39, 119-146.

Profanter, A. and Lintner, C. (2011). Sustainable intercultural integration in local communities: a pioneer project on intercultural education. Procedia - Social and Behavioral Sciences, 15, 1241-1247. https://doi.org/10.1016/j.sbspro.2011.03.270

Redfield, R., Linton, R. and Herskovitz, M. (1936). Memorandum on the study of acculturation. American Anthropologist, 38(1), 149-152. http://www.jstor.org/stable/662563

Salloumk, S., Siry, Ch. and Espinet, M. (2020). Examining the complexities of science education in multilingual contexts: highlighting international perspectives. International Journal of Science Education, 42, 14, 2285-2289. https://doi.org/10.1080/09500693.2020.1831644

Santos, B. S., Nunes, J. A. and Meneses, M. P. (2008). Introduction: opening up the canon of knowledge and recognition of difference. In Santos, B. S. Another knowledge is possible: beyond northern epistemologies (XIX - LXII). London: Verso Books. 
Swaidan, Z. (2018). Acculturation strategies of Asian-Americans. Competition Forum, 16(2), $39-45$.

Terranova-Cecchini R. and Toffle, E. (2014). Cultural integration in the contemporary world: using the cultural identikit. Procedia - Social and Behavioral Sciences, 159, 732-737. https://doi.org/10.1016/j.sbspro.2014.12.462

Tovar-Gálvez, J. C. (2021). The epistemological bridge as a framework to guide teachers to design culturally inclusive practices. International Journal of Science Education, 43(5), 760-776. https://doi.org/10.1080/09500693.2021.1883203

Tovar-Gálvez, J. C. and Acher, A. (2019). Relaciones entre la epistemología de las ciencias y las epistemologías tradicionales: contribuciones a la práctica didáctica. [Relations between the epistemology of science and traditional epistemologies: contributions to didactic practice]. CIMIE19, (1-7). Lleida: AMIE.

Tovar-Gálvez, J. C. and Acher, A. (2021). Design of Intercultural Teaching Practices for Science Education based on evidence. Enseñanza de las Ciencias, 39(1), 99-115. https://doi.org/10.5565/rev/ensciencias.2891

UNESCO. (2008). Inclusive education: the way of the future. Geneva: UNESCO.

Valladares, L. (2011). Un modelo dialógico intercultural de educación científica. [An intercultural dialogic model of science education]. Cuadernos Interculturales, 9(16), 119134. http://www.redalyc.org/pdf/552/55218731008.pdf

Wagener, A. (2009). In the Melting Pot: Integration, Assimilation, and Uniform Societies. [Working Paper]. Institute of social policy, University of Hannover.

Walsh, C. (2009). Interculturalidad, Estado, Sociedad Luchas (De) Coloniales de Nuestra Época. Quito: Universidad Andina Simón Bolívar.

Zainal, Z. (2017). Case study as a research method. Jurnal Kemanusiaan, 5(1). https://jurnalkemanusiaan.utm.my/index.php/kemanusiaan/article/view/165 